\title{
ORCID
}

Christopher Collins. 0000-0002-4398-6055

\section{Performing the Rural in Contemporary Irish Theatre}

This article considers how the rural is represented in contemporary Irish theatre through a performance analysis of WillFredd Theatre's award-winning production of FARM that was staged in an industrial Dublin warehouse. Adopting a relational perspective, the article explores how the rural in contemporary Irish culture is a valuable commodity that is produced for urban consumption. In so doing, the article examines how the representation of the rural in FARM offered a critique of economies of capital that obscure the inherent labour of producing the rural. The article also highlights how the performance explored the workings of the Irish cultural economy that produces rural nostalgia as an affective practice at the expense of some of the lived realities of rural life that extend beyond labour to loneliness, depression and gendered essentialism. Consequently, the article questions what - if anything - has changed from the representation and reception of the rural as nostalgic utopia, and the role nostalgia plays in articulating regional and national identities.

Key terms: Ireland, rural, space, commodity, nostalgia, affect.

The rural in contemporary Irish culture is a commodity that plays an important role in articulating regional and national identities. Cultural representations of the Irish rural are often formulaic, not very far from the rural represented in the St. Patrick's Day speech made by Taoiseach Éamon de Valera in 1943. In that speech de Valera advocated for 'the ideal Ireland' as a 'land whose countryside would be bright with cosy homesteads, whose fields and villages with be joyous with the sounds of industry'. ${ }^{1}$ De Valera's speech is part of a cultural process that uses rural nostalgia to other the rural in relation to the urban. Indeed, the otherness of rural nostalgia dominated twentieth-century Irish theatre, creating what Fintan O'Toole considers to be a stark 'contrast between the city and the country, [a] fictional division of the nation into a place of primeval innocence which has served ideologically to obscure the change that has taken place in the countryside'. ${ }^{2}$ Of course, the reality of rural Ireland is far removed from the commodified image of the cosy homestead, but formulaic representations 
and receptions of the Irish rural continue to facilitate the affects of nostalgia, or what Irish playwright Declan Hughes considers to be 'the illusion that there is something that still binds us together'. ${ }^{3}$

Contemporary Irish drama has done much to shatter the nostalgia for rural otherness, most notably in Marina Carr's On Raftery's Hill (2000). In that play, Carr represented the cosy homestead as a space steeped in intergenerational abuse. On Raftery's Hill premiered at the Town Hall Theatre, Galway, before transferring to the Royal Court Theatre, London. More recently, the play has been produced at the Abbey Theatre, Dublin, in 2018. Places of performance are important. For, while Carr's play demythologises fantasies of the rural, the spectator's gaze is still regularly positioned from the vantage point of the urban. As Jo Robinson has suggested, 'the rural often stands for a particular kind "otherness", to be visited and returned from, perhaps transformed', ${ }^{4}$ and it is with significance that the representation of rural in contemporary theatre 'is most often seen from the perspective of the city'. ${ }^{5}$ Representations of the rural in contemporary Irish theatre are often produced for urban consumption, thereby reflecting the complicated power relationships between the rural and the urban. It is also significant that On Raftery's Hill replicates the fourth wall of cottage-kitchen realism that only serves to foreground the fantasy of the rural from the perspective of the urban voyeur. While the content of rural representation is changing, the style, form and reception of rural representation in contemporary Irish theatre is limiting and limited.

Contemporary Irish theatre and performance has started to shift away from the predominance of the playwright to a devised practice. Founded in 2010, WillFredd Theatre is a company of devisers and co-collaborators who work with communities in order to provide introspection into the lived realities of those community members. To date performances include Follow (2011), devised with deaf and hard-of-hearing communities; Care (2014), devised with communities of hospice workers; Jockey (2015), devised with horse racing communities; and Bees! (2015), devised with bee-keeping communities. WillFredd's award-wining production of 
$\operatorname{FARM}\left(2012\right.$, revived in 2013) was devised with the members of Ireland's farming community. ${ }^{6}$ Set in an industrial Dublin warehouse the form of FARM was documentary theatre, but it was styled as a promenade performance with moments of audience participation. Consequently, the style of the performance deliberately challenged the hegemony of fourth wall, cottagekitchen realism. The dramaturgy of FARM's drama was reliant on interviews with members of Macra na Feirme (Keepers of the Land), a national community of local groups of farmers. These interviews were then used by WillFredd and their co-collaborators as the impetus to create different farming environments in the warehouse, some of which were staged managed by Macra na Feirme members. These farming environments were carefully orchestrated to include a working shire horse, two ducks, a tractor, hay bales, manure, carts, fences, gates, and other miscellaneous farming machinery. While it is important to point out that farming life is not a general index for the entirety of the rural, WillFredd created multiple farming environments in order to examine and explore multiple practices of rural space that extended far beyond farming life. In this way, WillFredd wanted to demonstrate that the farm is a microcosm of competing rural spatialities as opposed to the singular definition of the rural.

WillFredd marketed the production by claiming that 'there is a farmer inside everyone. How far from the land are you? The city has gone to seed but the price of sheep is going up. FARM asks what can rescue us? ${ }^{7}$ With the collapse of the Celtic Tiger economy in 2007 and subsequent $€ 440$ billion EU bailout in 2008 , WillFredd wanted to remind urban spectators that while the fiscal collapse of the nation took place in boardrooms in urban centres, the tremors were felt throughout the country, particularly in rural areas. Reflecting on contemporary Irish theatre since the collapse of the Tiger economy, Fintan Walsh has argued that 'the very fact that Ireland's boom was by and large a property boom has meant that its post-mortem would, to some degree, necessarily involve an examination of our relationship to space and place'. Indeed, WillFredd's mission statement is to 'submerse our audience in the totality of experience, making work that is spatially resonant, provoking questions and responses'. ${ }^{9}$ The space of an industrial Dublin warehouse allowed WillFredd to contest the complicated power 
relationship between the urban and the rural in contemporary Irish culture, a relationship that rarefies the politics of space and culture into the "big smoke" (the city) and "the country". The practice and participation of rural space in an urban place was essential to the dramaturgy of the performance. WillFredd envisioned the performance as a chance to interrupt the city centre [with] a space where the rural and the urban unite and bloom'. ${ }^{10}$ Into this warehouse WillFredd brought the economic and cultural politics of the rural in order to introduce urban spectators to alternative representations of the rural that were specifically curated to challenge their expectations of reception. 'Come to FARM, get your hands dirty, and unearth your roots'11 WillFredd advertised, and as spectators stepped through the fourth wall to encounter and experience rural space, WillFredd began to highlight rural-urban intersectionality and relationality. In turn, this allowed the performance to foreground one of its two most salient questions: 'how far from the land are you?'. ${ }^{12}$ Highlighting the intersections and relations between the urban and the rural necessarily posed questions and provoked responses about urban attitudes towards rural space. As a consequence, FARM foregrounded the politics of producing the rural for urban consumption, thereby demonstrating that production of the rural is never arbitrary and always political.

\section{Commodifying the Rural}

Commodities are defined by their exchange value. Karl Marx put the production of the commodity succinctly: "could commodities themselves speak, they would say: our use value may be a thing that interests men. It is no part of us as objects. What, however, does belong to us as objects, is our value. Our natural intercourse as commodities proves it. In the eyes of each other we are nothing but exchange values'. ${ }^{13}$ The use value of the commodity is defined by concrete labour, that is, the actual work put into its production. What is more important, however, is the abstract labour that regulates the exchange value of the commodity, usually in terms of monetary exchange. The production of all commodities involves the abstraction of concrete labour in order to compare different exchange values in the market place. For 
example, while it takes a lot of concrete labour to farm a potato, the monetary exchange value of this labour is abstracted in the market place as being not very valuable at all. As a consequence, the abstract labour required to produce a potato regulates the monetary value of a potato. This is why capitalism creates uneven development, simply because concrete labour is abstracted. The moment the commodity is exchanged (and therefore consumed) both labourer and consumer become part of the commodification process. 'This fetishism of commodities has its origin', Marx maintains, 'in the peculiar social character of the labour that produces them' ${ }^{14}$ In this way, the abstraction of labour is socially driven in relation to the value that people invest in certain commodities. As a consequence, the ways in which abstract labour defines value reveals what any given society holds valuable. As the use value of concrete labour is abstracted, the production and exchange of commodities begins to further define social relations as both labourer and consumer become alienated from the product. As commodity production increases, the world begins to appear as a commodity in which everything and everyone has an exchange value. From this perspective, the rural can be seen as a commodity that commands a specific value in the economic and cultural market place. Significantly, producing the rural is dependent on the rarefication of space into a homogenous entity that masks the concrete labour of its production in favour of its capital and cultural exchange value.

Rural spaces are commodified in relation to their multiple exchange values, all of which obscure the concrete labour involved in producing the rural. In an Irish context, rural space and its concomitant spatial practices have been commodified from tourist brochures to supermarkets. From this perspective, rural space is a valuable commodity because of its high exchange value. Governments, multinationals and global citizens exchange labour and economic capital for the commodification of Irish rural leisure, tourism, foodstuffs, and organic delicacies. In so doing, the inherent labour of producing rural space is obscured. The rural becomes a manufactured commodity as opposed to a space and place that people live, work and socialise in. At this point, it is important to remember that the commodification of the rural 
is often dependent on its relationality with the urban consumer; from the networks that facilitate food stuffs from rural periphery to urban centre, to the advertisement of weekend getaways. In short, consumption of rural commodities is complicit with the urban. In order to break the mystical aura surrounding commodities it is necessary to critique the exchange value of the commodity. Indeed, a successful critique of the exchange value that the commodity holds will result in the exposure of the commodity being of far more value than the abstract labour required to produce it. In FARM, WillFredd exposed the commodification of rural space by critiquing the exchange value of rural space from the urban centre.

The prologue to FARM exposed the exchange value of producing the rural. Spectators were ushered into a cramped corner of the warehouse that was sectioned off by large corrugated iron flats. This corner of the warehouse signified an office for all intents and purposes. In this office sat three suit-wearing real-estate brokers, each with their own toy farm figurines. Brokers arbitrarily altered the topographies of different make-believe farms in accordance with the exchange value of the figurines that each broker had in their possession. As is such, the use value of the rural commodity was critiqued as child's play with arbitrary exchange values. For example, three horses were exchanged for larger plots of land; four cows held more abstract labour than two fences and one pig, and therefore they had a more significant exchange value. Critiquing the arbitrary exchange value of rural space highlighted how the exchange value of the commodity is always inflated in relation to demand. From this perspective, while horses, land, cows, fences and pigs are certainly not worthless commodities, their exchange value is abstracted from their use value and, as a consequence, FARM exposed the fetishization of the rural commodity in the market place. That this process of fetishization was conducted by urban bureaucrats is important. Essential to Henri Lefebvre's understanding of the production of space is the role that 'bureaucratic and political authoritarianism immanent to a repressive space' plays. ${ }^{15}$ In this prologue, WillFredd highlighted that inherent in the production of rural space are people in powerful positions who are often far removed from the economic realities of rural life. For Lefebvre, capitalist 
bureaucrats conceive space as objectified by abstract labour as opposed to concrete labour. That is, bureaucrats do not simply conceive of space mentally, but actually produce it as an abstract commodity that disregards concrete labour and qualitive difference in favour of its exchange value, much in the same way that any other product in a factory is produced quantitively to be exchanged. As Lefebvre argues, 'capitalism and neocapitalism have produced abstract space, which includes the "world of commodities", its "logic" and its worldwide strategies, as well as the power of money and that of the political state. This space is founded on the vast network of banks, business centres and major productive entities'. ${ }^{16}$ Consequently, Lefebvre's major concern was the possibility that the production of abstract space will become a hegemonic commodity that underpins capital and cultural economies in relation to the exchange value of that space. From this perspective, space is not just a vacuum waiting to be filled, but a product that commands exchange value.

Just as abstract labour begins to define social conditions, the same can be said of abstract space which regulates how we perceive, conceive and live in any given space. Following Lefebvre, there is a very real danger that the rural emerges as a homogenous spatial commodity to be produced, packaged and sold in relation to its exchange value as opposed to a collection of individualised differential spaces. In his critique of space being produced as an abstract commodity, Lefebvre argued that 'the space that homogenizes has nothing homogenous about it'. ${ }^{17}$ While the rural might appear homogenous, it is anything but that. Therefore, it is important to critique the exchange value of the rural by exposing the concrete labour that is abstracted in the market place. In short, it is necessary to highlight the daily grind of producing the rural for urban consumption. FARM proceeded to do just this at the end of the prologue. As the brokers squabbled over the market value of toy figurines, corrugated iron flats were removed to reveal a working shire horse, Ralph. Ralph stormed through the office and into the full expanse of the industrial warehouse, and what had appeared as child's play moments before had now become real. Producing abstract rural spaces in an industrial warehouse situated on the edge of Dublin's financial quarter was rendered ironic as the 
concrete labour involved in producing the rural was now beginning to be exposed. With the fourth wall shattered and Ralph brought into his paddock, the three brokers removed ties, blazers and shoes and changed into muddy rubber boots. Now, with members of Macra na Feirme, actors - farmers - began establishing multiple farming environments in the warehouse. Referred to, and treated as cattle, spectators were goaded to the different environments with various hollers and calls of instruction. On the one hand, these multiple farming environments demonstrated that the rural has competing spatialities. Much more than this, however, the dramaturgy of these environments were carefully curated in order to challenge the commodification of rural space through a process of revealing the concrete labour inherent in rural production.

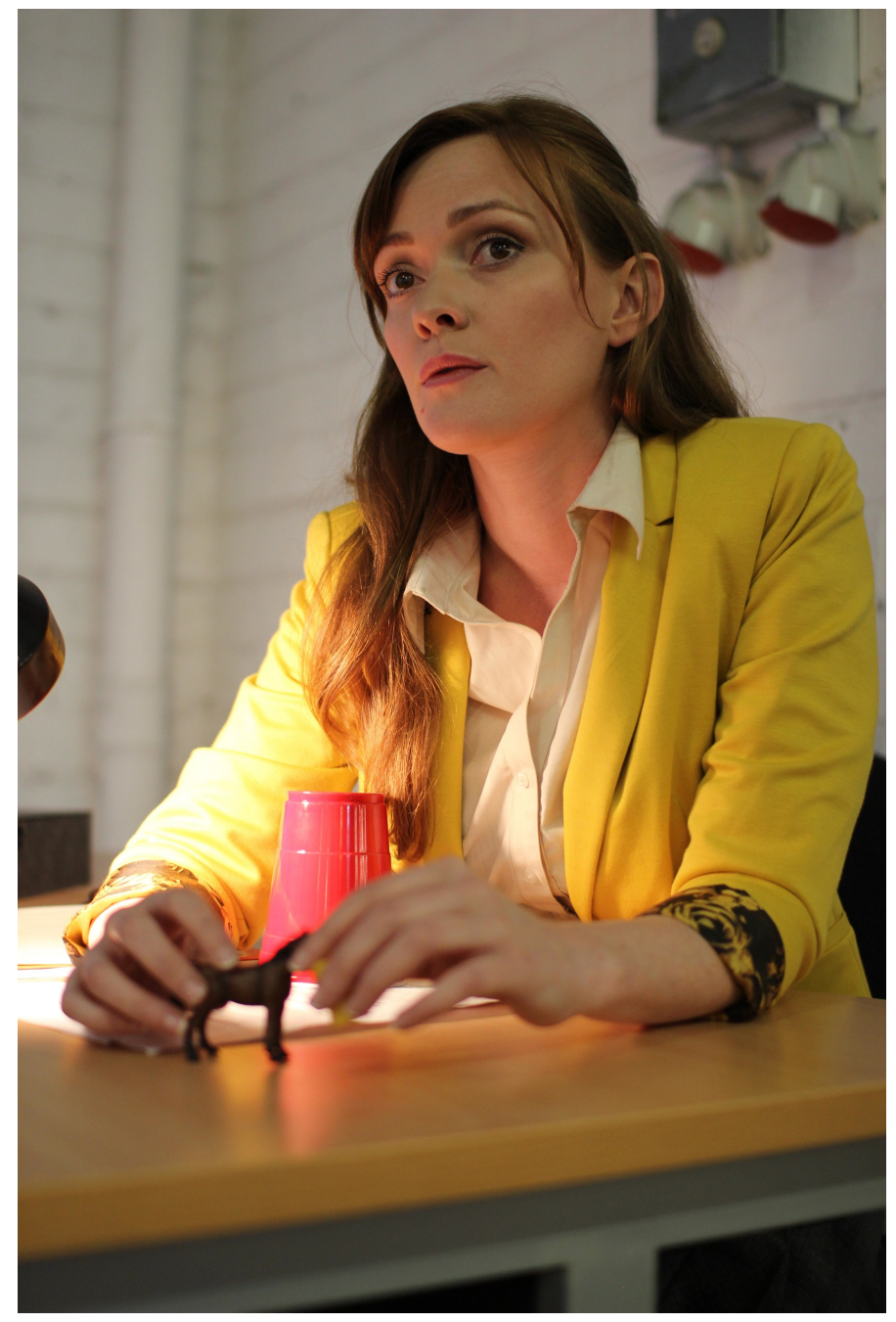

Producing the rural: abstract space

(c) Declan English and Killian Waters / Shoot to Kill, 2012. 
In one farming environment, spectators were introduced to an anthropomorphised cow who explained local knowledges of birthing practices during calving season. While dressed in a medical gown and standing in a pool of blood, the actor recounted the birthing process with intricate detail while demonstrating the uses of birthing equipment, which included the use of ropes, stocks and calving jacks. The decision to not use a real cow was significant, especially when other real farm animals were used in other environments. The demonstration of livestock equipment on a human made the labour inherent in rural production appear alienating to the urban consumer. This technique of alienation was repeated in another farming environment where one farmer sat at a table eating a roasted duck while explaining the process of farming ducks for a successful yield. Underneath the table he was sitting at, however, was a large cage with two real ducks lit by a spotlight. FARM highlighted that the process of producing and commodifying the rural requires the alienation of concrete, human labour predicated on use-value in favour of abstract labour predicated on monetary value. Exposing the labour involved in producing the rural was WillFredd's attempt to remind individual spectators that the commodification of the rural demands that the use value of farm animals are superseded by their exchange value in the market place. Accordingly, farm animals appeared as commodities to be produced for urban consumption, a process that necessarily requires the alienation of labour. As a consequence, the relationship between the urban and the rural was brought into sharp focus through the demonstration of the rural as a manufactured economy. Reminding urban spectators that they are quite possibly alienated from rural production, yet still inextricable to the commodification of the rural served to reveal the false perceptions of othering the rural as a homogenous abstract space. 


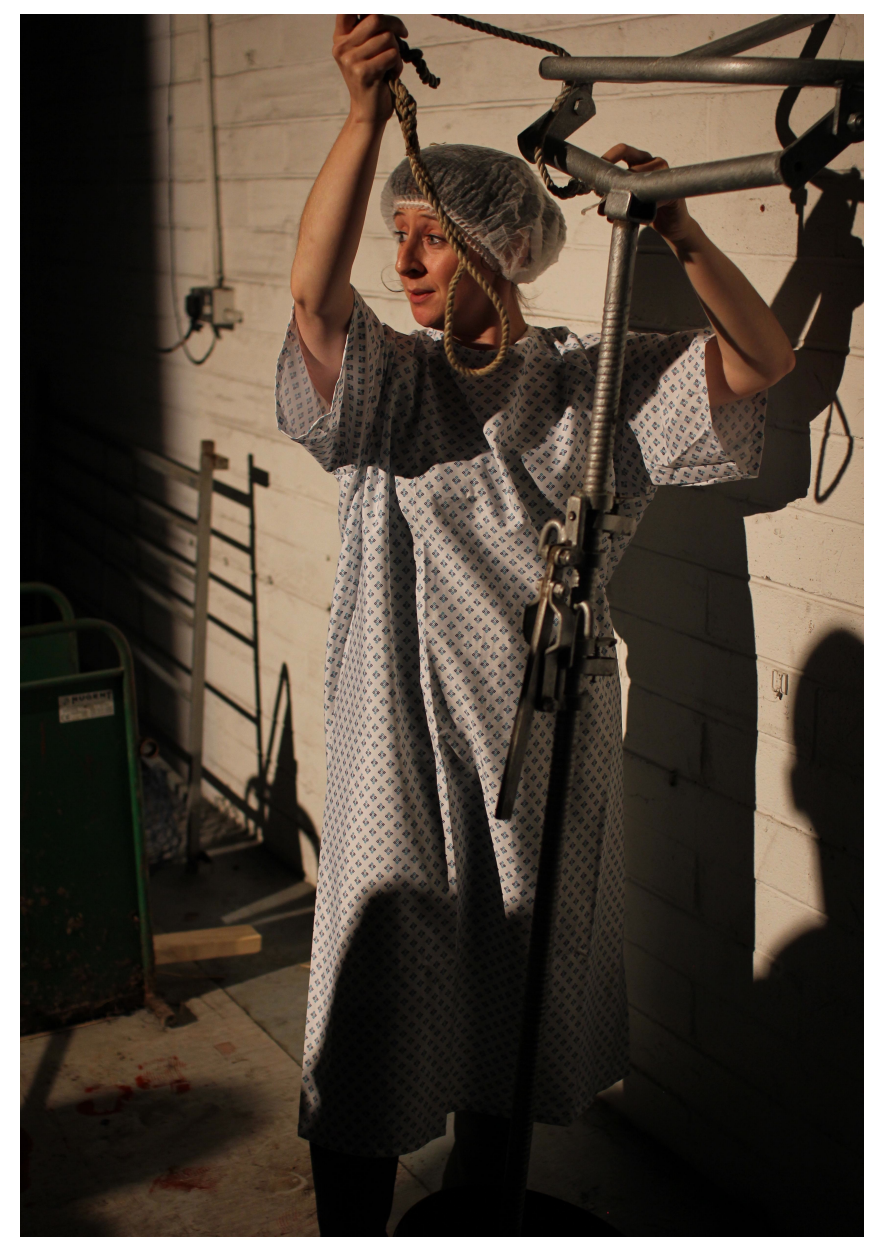

Producing the rural: calving season.

(C) Declan English and Killian Waters / Shoot to Kill, 2012.

Commodification of space results in what Doreen Massey advocates as the turning of 'geography into history, space into time'. ${ }^{18}$ According to this logic, certain spaces are discriminated against if they are unable to keep up with the dominant model of economic development. Indeed, the commodification of Irish agriculture for the global market means that those rural economies that cannot meet the expected productivist model of production are seen to be outmoded. In turn, this results in the production of the rural as a space that is economically inferior in relation to the urban. The economic division between the urban and the rural in contemporary Irish society dates back to the beginning of the Tiger economy in the 1990s when, as Diarmaid Ferriter points out, 'the divide between rural and urban widened [...] to the extent that the viability of some farming communities was seriously in doubt'. ${ }^{19}$ As a 
consequence, rural economies receive significant financial support. In 2012 (when FARM was first performed) the government in the Republic offered offer $€ 1.8$ billion financial aid to 136,476 farmers, with the average farmer receiving $€ 13,880 .^{20}$ The most recently published figures demonstrate that little has changed: in 2017 , the government again offered $€ 1.8$ billion financial aid to 130,118 farmers, with the average farmer receiving $€ 13,912 .{ }^{21}$ Governmental financial support to rural economies highlights the instability of farming life. It also highlights the pressure on rural communities to meet the economies of scale that the global marketplace demands.

Pressure on rural economies homogenises regional, local and familial knowledges of farming into a dominant model of production that ultimately commodifies the practice of space in accordance with urban demand. Lefebvre was apposite when he argued that the dominant form of space, that of the centres of wealth and power, endeavours to mould the space it dominates'. ${ }^{22}$ The domination of urban, abstract space attempts to mould the rural into an abstract commodity. The environments in FARM, however, further resisted the domination of abstract space beyond foregrounding the abstraction and alienation of concrete labour by highlighting the use value of local and regional knowledge. As is such, environments in FARM detailed local and regional knowledges of farming labour that were particular to different Macra na Feirme groups. Such regional knowledges extended from how to best combat carrot fly, to the most opportune month to send rams out to pasture. The production of these local knowledges highlighted their intrinsic use value that is deeply attached to space and place, as opposed to one generic farming methodology for the entire country. Caroline Crowley has argued that the commodification of space-specific farming knowledges has been compromised by 'the State's agricultural agents and large farmers, along with the farming media and mainstream framing organisations'. ${ }^{23}$ The creation of such a dominant network of knowledge and power exchange complicity supports 'the hegemony of the productivist paradigm underpinned by global knowledges to the detriment to local farming knowledges and has contributed to the economic and political marginalisation of the majority of farmers'. ${ }^{24}$ 
From this perspective, FARM resisted the commodification of rural space by demonstrating the use value and concrete labour of local knowledge.

\section{Rural Nostalgias}

If the economic production of the rural turns space into an abstract commodity, then it is important to remember that this mode of production is reciprocated in the cultural economy. The Irish rural is not simply an abstract economic space, but also an abstract cultural space that commands exchange value. One of Lefebvre's foremost critiques of the labour involved in producing space is that while all space can be perceived and conceived, there is significant labour involved in creating space in relation to its symbolic meaning that is both real and imagined. As Lefebvre argues, 'space is alive: it speaks. It has an affective kernel or centre [...] it embraces the loci of passion' ${ }^{25}$ For example, there is significant labour involved in the creation of rural space in relation to the image of the cosy rural homestead. For, while there are real cosy homesteads in the Irish rural, the labour of the imagination to invest the homestead with symbolic meaning turns a house into a commodity loaded with cultural symbolism with a high exchange value. Thus, the rural emerges as a cultural commodity that is abstracted from the lived reality of rural life. Significantly, a consensus of exchange value of rural space in both economies of capital and culture is created, and the one influences the other. This is why the aura surrounding the rural in contemporary Irish culture is hard to demystify.

Commodification of the Irish rural in the cultural economy is just as dependent upon turning geography into history, and space into time. Countless leisure and tourism adverts depict nostalgic images of green fields, cosy homesteads, and welcoming rural communities. Robinson has suggested that 'there is a tendency to persistently return to a green nostalgic and idelaised perspective as a "green world", ${ }^{26}$ and FARM was complicit in this strategy of representation. One of the most prominent environments in FARM was an elaborate barn 
dance. In this environment farmers jigged and reeled as spectators were encouraged to clap along to the rhythm of live music, their participation reinforcing the nostalgic representation of happy-go-lucky rural communities. However, WillFredd constructed these nostalgic scenes in order to critique the tendency to take such nostalgia at face value. From this perspective, just as FARM demythologised the rural by demonstrating the effects of labour production and commodification, the performance also demonstrated that nostalgia for the rural is equally produced and commodified. Nostalgia is concomitant with neoliberal economies that turn the past into a consumable cultural product that can be experienced and consumed in various forms for the right price, from vintage clothing stores to museum gift shops. If commodity culture influences the way in which the world is represented, then FARM explored how rural nostalgia is a consumable cultural gimmick, a by-product of the commodification or rural space in contemporary Irish culture. Accordingly, if the environment of the barn dance was conducive towards a cheerful consumption of rural nostalgia for a simpler life, then it was with significance that the environments that immediately followed the barn dance exposed the exchange value of rural nostalgia as a hyper-inflated cultural fantasy.

During the barn dance a lone male farmer broke free from the dance, picked up a pitchfork and began tending to a plot of land. Gradually the other farmers in the dance stopped and turned to watch what the farmer was doing. The lone farmer became increasingly frustrated with tending to his plot of land and eventually began scratching his pitchfork down the side of the industrial warehouse with tears in his eyes. Projected onto this wall were statistics of male suicide rates in rural areas. Michael Woods advocates that "high levels of depression and suicide among farmers have been linked to the self-doubt of farmers who feel that they are unable to match the expectations of the masculinist model of farming in an increasingly difficult economic environment'. ${ }^{27}$ Furthermore, Lisa Saugeres's research into gendered rural geographies has argued that 'farming is constructed as masculine, farmers' discourses and practices comes to reinforce and legitimate the boundaries that maintain this space as masculine'. ${ }^{28}$ In turn, the successful performance of a male farmer is 'maintained through a 
discourse emphasising physical strength and a natural aptitude for technology. ${ }^{29}$ The commodification of rural space does not simply affect geography, it also rarefies space in accordance with essentialised gendered divisions. Commodification of the rural demands that labourers become alienated and commodified in relation to the use value of their gender. When such gendered expectations are not realised it can have ruinous effects. Informed by a member of Macra na Feirme, environments such as this in FARM opposed the communal utopia of rural nostalgia.

Nostalgia is an affective practice. Brain Massumi has argued that 'the primacy of the affective is marked by a gap between content and effect'. ${ }^{30}$ The rural only becomes nostalgic due to the way it is represented; the effects of nostalgia are only able to affect people when the rural is represented nostalgically. If the rural is not represented nostalgically, then it loses the affective power of nostalgia and, all of a sudden, the rural utopia is revealed to be a simulacra. However, the problem is that representations of rural nostalgias have a high exchange value in the cultural market place, as demonstrated by the final environment in FARM that focussed on collective experiences of rural nostalgia. In this environment the cast, crew, members of Macra na Feirme, and audience members sat on hay bales with animals in close proximity exchanging fond memories of the rural, singing songs, and drinking free mead. This environment was a testament to WillFredd's community-engaged practice, but it also indulged in rural nostalgia as an affective product of abstracted rural space. According to Lefebvre, when space is abstracted, "lived experience is crushed, vanquished by what is "conceived of" [and] history is experienced as nostalgia'. ${ }^{31}$ Nostalgia manipulates experiences of time and space, and FARM's final environment was problematic because it compressed Macra na Feirme's experiences and histories of rural time and space into a nostalgic commodity. If nostalgia for the rural had previously been advertised as a manufactured cultural product concomitant with the commodification of rural space, it was now being part-exchanged for its affective power in an economy of experience. Significantly, Lefebvre maintained that 'affectivity, which along with the sensory/sensual realm, cannot accede to abstract space'32 
because capitalism distorts lived experiences of space, rendering them impersonal. However, what Lefebvre overlooked, and what FARM established, is that nostalgia is an affect of commodified rural space. The final environment in FARM demonstrated that capital does not simply produce abstract rural spaces with no affective power, but quite the opposite. Capital turns rural space into a commodity with a high exchange value in the cultural marketplace because it is affective; the rural retreat comes at a cost, but it will afford an experience beyond knowledge or description. Indeed, FARM offered urban audiences a temporary rural retreat, highlighting that nostalgia for the rural never really fades away because it is continually produced by a cultural economy that responds to fluctuations in capital. When the urban becomes too much, the simpler life of the country is escaped to because it has affective power. If Lefebvre feared that abstract space will become a hegemonic commodity upon which economies of capital and culture are predicated, then FARM exposed an uncomfortable truth. That is, the affective power of the rural supports the commodification of rural space. In the wake of the financial crash, FARM answered the performance's pressing question, 'what can save us? ${ }^{33}$ with a simple answer: rural nostalgia.

Contemporary psychological analysis of the affective practices of nostalgia maintain that nostalgia 'strengthens a sense of social connectedness' ${ }^{34}$ Indeed, Irish Theatre Magazine's review of the performance advocated that ' $F A R M$ has given us a feeling of having created a community, while simultaneously feeling its loss in the larger world'. ${ }^{35}$ This review encapsulates the nostalgic desire for the creation of a community predicated on shared experience in the face of uncomfortable change. It also neatly summarises Hughes's frustration over performing rural nostalgia in contemporary Irish theatre because it creates 'the illusion that there is something that still binds us together'. ${ }^{36}$ Indeed, consideration of nostalgia as being able to create a sense of community radically homogenises modes of reception. 'Come to FARM, get your hands dirty, and unearth your roots', ${ }^{37}$ WillFredd asked, and while these words were selling a performance, they also reinforced the production of rural nostalgia in the Irish cultural economy. Not everyone has roots in the rural, but it could be 
experienced, and one could belong to a community in FARM - if one was willing to pay. From this perspective, while the affective connection of cast, crew and audience members might have been increased, rural nostalgias were still created and consumed for the cultural appetites of urban audiences, and if a community was created it was manufactured and disposable. Not everyone wants to get their hands dirty. The prologue and subsequent environments of FARM clearly foregrounded the uneven relationality between the urban and the rural by demonstrating how it is produced as a space in which labour is alienated and its inherent use value is abstracted. However, the ending of the performance reinforced the uneven relations between the rural and the urban as the consumption of rural nostalgia was exchanged for the price of a theatre ticket. That WillFredd decided to place this environment at the end of the performance obscured their own concrete labour of producing rural space. When so much of the performance had worked hard to expose the commodification of the rural in economies of capital and culture, it was ironic that the takeaway experience was one of nostalgia. Performing nostalgia should heighten the effects of performance because it necessarily involves experiences of the past in the present as a way of examining the here and now. However, as audience members sat on hay bales recounting past experiences of rural time and space, the affects of nostalgia dominated any performative effects. As is such, any use of nostalgia to shape awareness of the production of rural space was not fully substantiated.

FARM demonstrated that while the style and form of rural representation in Irish theatre and performance has progressed beyond the hegemony of fourth wall, cottage-kitchen realism, some emotions such as rural nostalgia have considerable influence on the reception of the rural from urban perspectives. Contemporary representations of the rural in Irish theatre might proceed to use contemporary strategies of alienation to highlight the commodification of the rural, but alienation cannot always supersede the exchange value of the rural commodity and the concomitant effects of nostalgia. If Hughes once issued a directive to theatre makers to avoid 'perverse nostalgia: nostalgia for the time when we think we were Irish, when we had 
an identity [...] that corrodes at every level', ${ }^{38}$ then FARM demonstrated that there is still a struggle over the representation and reception of the rural in contemporary Irish culture. Reductive representations and receptions of the rural in contemporary Irish theatre and performance only serve to homogenise and reinforce regional and national identities, and in an age of ever-increasing localism this is problematic. Indeed, it is even more problematic that representations and receptions of the Irish rural are biased in favour of the urban. FARM highlighted the relationality between the urban and the rural, but ultimately urban consumption of the rural is still very much predicated on objectifying the rural for its exchange value. Ironically, performing the rural in contemporary Irish theatre is still an urban experience.

\footnotetext{
${ }^{1}$ Éamon de Valera, "Address by Mr. De Valera". https://www.rte.ie/archives/exhibitions/eamon-de-valera/719124-address-by-mr-de-valera/ Accessed 8 March, 2018.

2 Fintan O'Toole, 'Going West: the Country Versus the City in Irish Writing', The Crane Bag, IX, No. 2 (1985), p. 115.

${ }^{3}$ Declan Hughes, 'Who the Hell Do We Think We Still Are? Reflection on Irish Theatre Identity', in Eamonn Jordan, ed., Theatre Stuff: Critical Essays on Contemporary Irish Theatre (Dublin: Carysfort Press, 2000), p. 13.

${ }^{4}$ Jo Robinson, Theatre \& The Rural (London: Palgrave, 2016), p.17

${ }^{5}$ Ibid.

${ }^{6}$ FARM won the best off-site production and the Lir Revival awards at the Absolute Fringe Festival, 2012. It was ranked second in www.entertainment.ie's top ten productions of 2012. It was also nominated for best production at the 2013 Irish Times theatre awards.

${ }^{7}$ Absolute Fringe Festival Programme, Dublin Fringe Festival 2012, p. 93.

${ }^{8}$ Fintan Walsh, 'The Power of the Powerless: Theatre in Turbulent Times', in Fintan Walsh, ed., "That Was Us", Contemporary Irish Theatre and Performance (London: Oberon, 2013), p. 11

${ }^{9}$ Listing for WillFredd Theatre, Irish Theatre Institute Website. See, http://www.irishtheatre.ie/company-page.aspx?companyid=30422. Accessed 19 July, 2018.

${ }^{10}$ Absolute Fringe Festival Programme, Dublin Fringe Festival 2012, p. 93.

11 lbid.

12 lbid.

${ }^{13}$ Karl Marx and Frederick Engels, Collected Works, Vol. XXXV (London: Lawrence \& Wishart, 1996), pp. 93-94.

14 Ibid., p. 81.

${ }^{15}$ Henri Lefebvre, The Production of Space (Oxford: Blackwell, 1991), p. 49.

${ }^{16}$ Ibid., p. 53.

17 Ibid., p. 309.

${ }^{18}$ Doreen Massey, For Space (London: Sage, 2005), p. 5.

${ }^{19}$ Diarmuid Ferriter, The Transformation of Ireland: 1900-2000 (London: Profile, 2005), p. 666.

20 'Annual Review \& Outlook for Agriculture Food and the Marine 2012/2013', An Roinn

Talmhaíochta, Bia agus Mara/Department of Agriculture Food and the Marine, 2013, p. 14.

21 'Annual Review \& Outlook for Agriculture Food and the Marine 2018' An Roinn

Talmhaíochta, Bia agus Mara/Department of Agriculture Food and the Marine, 2018, p.18.
} 
${ }^{22}$ Lefebvre, The Production of Space, p. 49.

${ }^{23}$ Caroline Crowley, 'Ancestors in the field: Irish farming knowledges' in Caroline Crowley and Denis Linehan, eds., Spacing Ireland: Place, Society and Culture in a Post-Boom Era (Manchester. Manchester University Press 2013), pp. 145-46.

24 Ibid., p. 146.

${ }^{25}$ Lefebvre, The Production of Space, p. 42.

${ }^{26}$ Robinson, Theatre \& Rural, p. 3.

${ }^{27}$ Michael Woods, Rural (London, Routledge, 2011), p. 220.

${ }^{28}$ Lisa Saugeres, 'Of Tractors and Men: Masculinity, Technology and Power in a French Farming Community', Sociologia Ruralis, XLII, No. 2 (2002), p.156.

${ }^{29}$ lbid.

${ }^{30}$ Brian Massumi, 'The Autonomy of Affect', Cultural Critique, XXXI, No. 2 (1995), p. 84.

Emphasis in original.

${ }^{31}$ Lefebvre, The Production of Space, p. 51.

32 lbid.

${ }^{33}$ Ibid.

${ }^{34}$ Clay Routledge, Constantine Sedikides, Tim Wildschutt, and Jacob Hill, 'Finding Meaning in One's Past: Nostalgia as Existential Resource', in Keith D. Marjman, Travis Proulx, and Matthew J. Lindberg, eds., The Psychology of Meaning (Washington, D.C.: American Psychological Association, 2013), p. 312.

${ }^{35}$ Susan Conley, 'Absolut Fringe 2012: FARM'. See, http://itmarchive.ie/web/Reviews/Current/Absolut-Fringe-2012--FARM.htmI SUSAN CONLEY. Accessed 27 July, 2017.

${ }^{36}$ Hughes, 'Who the Hell Do We Think We Still Are? Reflection on Irish Theatre Identity', p. 13.

${ }^{37}$ Absolute Fringe Festival Programme, Dublin Fringe Festival 2012, p. 93.

${ }^{38}$ Hughes, 'Who the Hell Do We Think We Still Are? Reflection on Irish Theatre Identity', $p$. 11. 